\title{
THE PRIMACY AND SUPREMACY CLAUSES OF EUROPEAN UNION LAW AND THEIR APPLICATION IN THE LEGAL ORDER OF THE REPUBLIC OF LITHUANIA
}

\author{
AS CLÁUSULAS DE PRIMAZIA E SUPREMACIA DO DIREITO COMUNITÁRIO EUROPEU E SUA \\ APLICAÇÃO NO ORDENAMENTO JURÍDICO DA REPÚBLICA DA LITUÂNIA
}

\section{Pavelas Ravluševičius*}

\begin{abstract}
:
The primacy and supremacy clauses of European Union law ("EU law") are to one of the most prevalent issues concerning the relationship between EU law and domestic law of the Republic of Lithuania. It seems that such issues were not definitely settled even when the Treaty of Lisbon amending the Treaty on European Union, which established the European Community. During that period, significant changes were made in EU Member States, regarding the domestic application of the principle of primacy and supremacy of EU law. Lithuanian law has undergone the development in this sphere too.

The European Court of Justice ("ECJ") has developed the meaning of the principle of primacy, which means that European Union law should take precedence over the national law (even over constitutional provisions) and, in case of conflicts between EU law and national law, every national court is obliged to apply the European Union law. The comparative analysis of the Lithuanian Constitutional Court case law shows counter development to the ECJ case law, which may cause the jurisdictional collision of setting aside EU law based on constitutional grounds.

The paper includes some relevant examples of application of EU law arising from preliminary ruling procedure under Art. 267 of Treaty on the Functioning of the European Union in the praxis of the Lithuanian Constitutional Court and Lithuanian courts of general and special competences.
\end{abstract}

Keywords: Primacy of European Union Law. Competences of the European Union and the Member States. Judicial Control of the Court of Justice of the European Union and the Courts of the Republic of Lithuania.

\begin{abstract}
Resumo:
As cláusulas de primazia e de supremacia do direito comunitário europeu são um dos principais temas concernentes à relação entre este direito e o direito nacional da República da Lituânia. Parece que estes assuntos não foram definitivamente pacificados quando da elaboração da emenda ao Tratado de Lisboa, o qual emendou o Tratado da União Europeia, quando este entrou em vigor. Durante esse período, mudanças significativas ocorreram nos Estados-Membros, em relação à aplicação interna dos princípios da primazia e da supremacia do direito comunitário europeu. O direito lituano também experimentou esse desenvolvimento nessa esfera.
\end{abstract}

\footnotetext{
* Pavelas Ravluševičius Dr. jur. LL.M. Associate Professor at the European Humanities University, Program of International and European Union Law, E-mail: pavelas.ravlusevicius@ehu.lt.
} 
A Corte Europeia de Justiça desenvolveu o significado de princípio da primazia, que significa que o direito comunitário europeu deve ter precedência sobre o direito nacional (inclusive em matéria constitucional) e que, em caso de conflitos entre o direito comunitário europeu e o direito interno, cada corte nacional é obrigada a aplicar aquele direito. A análise comparativa da jurisprudência da Corte Constitucional da Lituânia aponta em sentido contrário ao da jurisprudência da Corte Europeia de Justiça, o que pode causar conflitos jurisdicionais na definição do direito da União Europeia baseado em termos constitucionais.

Este artigo inclui alguns exemplos relevantes da aplicação do direito da União Europeia que surgem de regras preliminares do art. 267 do Tratado de Funcionamento da União Europeia na práxis da Corte Constitucional da Lituânia e nas demais cortes daquele país.

Palavras-chaves: Primazia do direito da União Europeia. Competências da União Europeia e dos Estados Membros. Controle judicial da Corte Europeia de Justiça e das Cortes da República da Lituânia.

\section{Introduction}

The law of the European Union (EU law) had an enormous influence after the accession of the Republic of Lithuania into the European Union on the Lithuanian legal order that assumes the most difficult issue of the relationship between EU law and Lithuanian law.

The entering into force the Treaty of Lisbon, and especially its declaration No. 17 on primacy of EU Law, made the relationship to the domestic law of the EU Member States one of the quite often applicable issues in the European Court of Justice ("ECJ") case law and domestic courts of the Republic of Lithuania. The legal integration between the EU and Lithuania characterized the process of fusion of the two different legal orders. This paper will explain the meaning of primacy of EU law and its relationship to the supremacy, priority and precedence of EU law that are used in the ECJ case law and the Lithuanian Constitutional Court. The main purpose of the paper is to analyse the development of the ECJ judgments in cases brought before Lithuanian courts in the areas related to EU law, to prove that different developments arose at a level of EU law and the one of domestic law. It also includes relevant provisions of the Treaty of Lisbon that deal with the rules concerning the legal requirements on the primacy and supremacy clauses of EU law.

Taking into account the subject matter of the research, the present paper has the following structure. The first part of the paper analyses the issue of the transfer of powers, which could have an impact on the actions from the Lithuanian authorities to the European Union institutions. Constitutional legitimisation of transfer of competences was enacted through the Constitutional Act of the Republic of Lithuania on the Membership of 
Lithuania in the European Union. Consequently, the rules of EU law and the Constitutional Act on the Membership of Lithuania in the European Union should be analysed together. The second part of the paper deals with the legal issue of the primacy and supremacy clauses of EU law in EU law. The primacy principle in the Declaration No. 17 of the Treaty of Lisbon should bring new points for the enforcement of EU law at the domestic level. The subsequent parts of the paper analyse the cooperation issues between the ECJ and national courts. The main cause of such cooperation is avoiding collisions between the national law and EU law and recognition of the primacy and supremacy clauses of EU law. This issue was particularly elaborated in the Constitutional Court of the Republic of Lithuania case law, as in the relationship with EU law it gives priority to the constitutional guaranties. Such a position of the Constitutional Court of the Republic of Lithuania may cause contradictions between EU law and Lithuanian law. The paper has taken as a result of the comparative analyses the examples the influences of Constitutional Courts from other EU Member States related to the Lithuanian case law. The purpose of this paper is to prove that different developments arose at a level of EU law and the one of domestic law. Finally, the current paper intends to make proposals of how to avoid such possible contradictions.

2. The Competence of European Union and Constitutional Act "On the Membership of the Republic of Lithuania in the European Union"

The Treaty of Lisbon explicitly stipulated the catalogue of the competences that belongs to the European Union. Art. 5 of the Treaty of the European Union ${ }^{1}$ states $^{2}$ that all kinds of the competences of the European Union are governed by the principle of conferral of competence. The previous rules coming from the ECJ case law and praxis of the European Union Institutions were replaced and in many points changed by the Treaty of Lisbon. The introduction of a catalogue of competences in the Treaty on the Functioning of the European Union ${ }^{2}$ had a clear purpose of eliminating the overlap between the lawmaking powers of the European Union and a EU Member State. European Union Institutions apply the rules of the competence in their activities and that may have an impact on the provisions of the Constitution of the Republic of Lithuania. The issue of the legislative powers of European Union comes together with the issue on the relationship between the European Union and Constitutional Law. But the application of EU law shows certain difficulties, remembering the provisions of the "Costa v E.N.E.L." decision, when

Treaty of the European Union, Official Journal of the European Union C 83/13 of 30. March 2010.

2 Treaty on Functioning of the European Union, Official Journal of the European Union C 83/47 of 30. March 2010. 
the ECJ stated that the powers had been transferred from the States to the Community in such a way that "the Member States have limited their sovereign rights". ${ }^{3}$ It is remarkable that the Declaration No. 17 concerning primacy ${ }^{4}$ of the Treaty of Lisbon indicates the "Costa v E.N.E.L." decision as the leading case for the recognition of the primacy of EU law and requires EU Member States to recognize the ECJ case law stemming from the "Costa v E.N.E.L." decision. However, as a matter of fact the development of EU Law demonstrated how sensible the issues of transfer of the sovereign powers to the European Union are. In 1964, no one imagined that the limitation of sovereign powers of the EU Member States would be having the same meaning in the Treaty of Lisbon from 2009.

Actually, the Constitution of the Republic of Lithuania came into force on 2 November $1992^{5}$ and has made difference between sovereignty of nationals and sovereignty of a State. Sovereignty of the State is to be understood as powers of the institutions of the government of Lithuania. It is important to take this difference into account. According to the Lithuanian Constitutional Court case law, any limitation of sovereignty cannot be allowed. ${ }^{6}$ Art. 2 of the Lithuanian Constitution prescribes that sovereignty shall belong to the Nation. Art. 3 of the Constitution explicitly states that no one may limit or restrict the sovereignty of the Nation or make claims to the sovereign powers of the Nation.

Consequently, Art. 1 of the Constitutional Act On the Membership of the Republic of Lithuania in the European Union stipulates, that the Republic of Lithuania, as a Member State of the European Union, shall share with or confer on the European Union the competences of its State institutions in the areas provided for in the founding Treaties of the European Union and to the extent that, together with the other EU Member States. It would, together with other EU Member States, meet its membership commitments in those areas as well as enjoy the membership rights. ${ }^{7}$

The analysis of the Lithuanian Constitutional Act allows making a conclusion that its rules accepts and recognize the opposite: an application of the principle of limitation of European Union powers. It means that the limitation of the sovereign powers according to the "Costa v E.N.E.L." decision could be understood as

ECJ 15. July 1964, Case 6-64, p. 5, Flaminio Costa v E.N.E.L. reference for a preliminary ruling: Giudice conciliatore di Milano - Italy.

4 Declaration No. 17 concerning primacy, Official Journal of the European Union C 83/344 of 30. March 2010.

5 Constitution of the Republic of Lithuania, Official Gazette Nr. 33-1014 of 30. November 1992.

6 Judgment of the Constitutional Court of the Republic of Lithuania 22. June 2009 About the legal act of territorial planning Nr. 16/07-17/07-20/08.

7 Law on Supplementing the Constitution of the Republic of Lithuania with the Constitutional Act "On Membership of the Republic of Lithuania in the European Union" and Supplementing Article 150 of the Constitution of the Republic of Lithuania No. IX-2343, Official Gazette 2004, Nr. 111-4123. 
a contradiction to the legal provisions of the Constitution of the Republic of Lithuania. Actually, it is difficult to find in the jurisprudence of the ECJ the special explanations of the meaning of the limitations of sovereign rights according to the judgment of "Costa $\mathrm{V}$ E.N.E.L."

The current practice of the ECJ tries to avoid any specific contradictions to the issues of national sovereignty. In such cases the ECJ usually applies the legal principle of subsidiarity, as a rule for delimitation of extensional powers of the European Union. Such a trend has clearly manifested itself in the recent jurisprudence of the ECJ. ${ }^{8}$ The national legislative may act in many fields claiming that it belongs to the level of constitutional guarantees which precludes a prerogative of application of EU law in the domestic legal order. Under some circumstances, it could stop the application of EU law and be an obstacle for its enforcement. ${ }^{9}$

\section{Primacy and Supremacy Clause of European Union Law in EU Law}

During the accession of the Republic of Lithuania into the European Union, the legal rules in the Treaty of the European Union and Treaty of European Community did not contain any "lex scripta" provisions on the primacy and supremacy of EU law over domestic law of the EU Member States.

The Treaty of Association of the Republic of Lithuania to the European Union $^{10}$ and the Treaty of Accession of the Republic Lithuania to the European Union ${ }^{11}$ did not include any legal rules about the relationship of EU law to the Lithuanian law. Moreover, the Republic of Lithuania has not negotiated with the European Union the issue of the primacy (supremacy, precedence) and the direct applicability of EU law in their domestic law. The European Union Institutions have never implicitly made this issue to the matter of negotiations because according to the "acquis communautaire" the full enforcement of EU law belonged to the basic condition of accession of the Republic of Lithuania to the European Union. According to them, each EU Member State has an obligation to implement it and enforce the obligations of EU law. If the EU Member State

8 ECJ 12. May 2011, Case C-176/09, p. 82, Grand Duchy of Luxembourg / European Commission; ECJ 8. June 2010, Case C-58/08, p. 72, Vodafone Ltd and others; Court of first instance 23. September 2009, Case T-263/07, p. 52, Republic of Estonia / Commission of the European Communities.

9 M. Kumm, The jurisprudence of Constitutional Conflict: Constitutional Supremacy in Europe before and after the Constitutional Treaty, European Law Journal (2005) Vol. 11, No. 3, p. 262.

10 Treaty of Association of the Republic of Lithuania to the European Union, Official Gazette Nr. 11-266 of 31. January 1998.

11 Treaty of Accession of the Republic Lithuania to the European Union, Official Gazette Nr. 1-1 of 02. January 2004. 
fails to do so, such could be treated as a violation of the Accession Treaty and "acquis communautaire" of the European Union.

Nevertheless, some efforts to change the level of regulation on the primacy of EU law could be noticed. In 1996 the Amsterdam Treaty Draft (called Cambridge Draft) constituted the first effort to introduce regulation on the primacy of EU law into the primary law of the European Union. Article I.1.6 of the Amsterdam Treaty stipulated the principle of the primacy of EU law as the following rule "(3) In the event of conflict between provisions applicable under the legal orders of the Member States (hereinafter referred to as "national provisions") and directly effective Community provisions, the latter shall prevail. To that end, a court or tribunal of a Member State shall refrain, if necessary of its own motion, from applying national provisions in all cases in so far as these conflict with any Community provisions applicable to matters of which the court or tribunal is seized."12

Paragraph (3) was a codification of the case law that the ECJ had developed at the time. The EU Member States had the duty to apply EU law in the case of conflict with the national legal provisions. The Cambridge Draft has stressed that EU law should take over the national law, because it is supreme law. However, the Cambridge Draft of the Amsterdam Treaty was not successful. ${ }^{13}$

The second effort to enact a legal rule concerning the primacy of EU law in EU primary law was in 2004, when the provisions of the Treaty establishing a Constitution for Europe were under consideration. Article I-6 "Union law" of the Constitutional Treaty stated that the constitution and the law adopted by the European Union Institutions in exercising competences conferred on it should have the primacy over the law of the EU Member States. ${ }^{14}$ Under the wording of this Article, the national legal orders of EU Member States should have recognized the primacy of EU law without any exceptions. However the factual situation was different. Due to such an unsuccessful ratification of the Constitutional Treaty, this reform has been laid in the history of the recent development of EU law. ${ }^{15}$

A relatively successful attempt was achieved in the Treaty of Lisbon, which included a separate Declaration No. 17 concerning the primacy of EU law. Pursuant to

\footnotetext{
$12 \quad$ European L. Rev. 22, 393 (1997).

13 C.U. Schmid, Ways Out of the Maquis Communautaire on Simplification and Consolidation and the Need for a Restatement of European Primary Law, European University Institute, Working Paper (1999) RSC No 99/6; K. Hasselbach, Der Vorrang des Gemeinschaftsrechts vor dem nationalen Verfassungsrecht nach dem Vertrag von Amsterdam, JZ (1997) p. 942.

14 Treaty establishing a Constitution for Europe Official Journal of the European Union C 310/12 of 16. December 2004.

15 R. Barents, The Precedence of EU Law from the Perspective of Constitutional Pluralism, European Constitutional Law Review (2009) 5, p. 421-446.
} 
this declaration, the primacy of EU Law should be recognized as a cornerstone principle of EU law. The text of Declaration No. 17 characterized the specific nature of EU law. The legal definition of the principle of primacy is based on the opinion of the Council Legal Service on 22 June 2007 about the ECJ case law in the case Costa v. E.N.E.L. of 15 July 1964, Case No. 6/641. According to the statement, the fact that the principle of primacy will not be included in the future treaty shall not in any way change the existence of the principle and the existing case law of the Court of Justice. ${ }^{16}$ Remarkably, that the ECJ has not directly used the term of primacy in the text of the judgment concerning Costa v. E.N.E.L. case. ${ }^{17}$

The comparative analysis of EU law primacy clause in the Treaty of Lisbon, as well as the proposal in the Amsterdam Treaty and the Treaty establishing a Constitution for Europe, shows at first look that the Declaration No. 17 on primacy has less on obligatory power to the EU Member States. The regulatory level of declaration is compensated through the reference to ECJ case law, which should enforce the primacy of EU law in the relationship to the domestic law.

Actually, Declaration No. 17 belongs to the primary law of the European Union and has the same obligatory level as the Treaty of Lisbon itself. The incorporation of the primacy principle in Declaration No. 17 of the Treaty of Lisbon constitutes a kind of revision of the existing legal system of the European Union and should be understood as the answer to the statements regarding the supremacy of the national constitutions made by the Constitutional Courts. ${ }^{18}$ The transformation of the International Law usually depends on the provisions of the Constitutional Law or the State that allows direct applicability of the international norms and its priority over the domestic law. It is a matter of transformation into the national law and cannot influence the international obligation of the State to fulfil the concluded international treaties. Now, the question is, if the principle of primacy as stated in Declaration No. 17 of the Treaty of Lisbon and developed by the ECJ case law becomes a codified constitutional principle of EU law. Moreover, it is the most frequently addressed issue in the judgments of the ECJ and most related to the enforcement of European Union law in the domestic legal order.

16 Declaration Nr. 17 concerning primacy; Annex to this Final Act the Opinion of the Council Legal Service on the primacy of EC law as set out in 11197/07 (JUR 260).

17 Flaminio Costa v E.N.E.L., supra n. 3.

18 M. Kumm, supra n. 9, p. 272. 
4. The primacy and supremacy clauses of EU law in the European Court of Justice case law

It should be stressed that the primary purpose of the ECJ case law was to control the legal actions of European Union Institutions (especially the European Commission). ${ }^{19}$ In the beginning, the issue primacy and supremacy of EU law was not a relevant issue in the ECJ case law. The situation changed when different applications of EU law required the necessity of unified enforcement of EU legal rules in different EU Member States. It was clear that clashes between EU law and the national law could not be avoided. One characteristic point is that the ECJ started to use different terms in its practice. In various judgments of it is possible to find of the following terms describing the issue: "supremacy", "primacy" and "precedence".

The supremacy and primacy of EU law can have different meanings. Supremacy is dealing with the application of valid regulations and deciding on the hierarchy of legal rules in the law system. ${ }^{20}$ Primacy is based on priorities by the application of legal rules that do not necessarily have something in common with the hierarchical issues. According to Amatos and Ziller, supremacy does always imply primacy, unless the same supreme regulation sets its own displacement or non-application. ${ }^{21}$

Remarkably enough, the ECJ has not completely clarified this topic yet. Specifically, such terms as "supremacy", "precedence" and "primacy" are often used in the court case law together. The different usage of terms took place in the beginning of this kind of case law and such practice still exists. But all such cases have a common point of finding solutions in instances of collision between rules of EU law and domestic law. The analysis of the ECJ case law gives the results that the term of the supremacy is rarely to find. This court avoids the use of this term in the recent case law. For example, the advocate General Jaaskinen used the term "supremacy", by stating the fact that the EU secondary legal act (Regulation No 1408/71) could not contradict EU primary law, which contains the supreme principle of the equal treatment. ${ }^{22}$

Similar technique of the interpretation of the supremacy clause has been used by the advocate General Mazak, when said that the national measures which were adopted prior to EU - Regulation No 1626/94 have no legal basis under that regulation and no longer continue in force, due to the principle of supremacy of the provisions of the

\footnotetext{
19 K.J. Alter, Establishing the Supremacy of European Law - The Making of an International Rule of Law in Europe (Oxford-University Press 2001) p. 5.

20 J.H. Reestman, Primacy of Union Law, European Constitutional Law Review (2005) 1, p. 104-107.

21 G. Amato / J. Ziller, The European Constitution - Cases and Materials in EU and Member States Law, Primacy of EU Law (Edward Elgar 2007) p. 99.

22 Opinion of Advocate General Jaaskinen, Case C-345/09, 15. July 2010, p. 61.
} 
regulation. ${ }^{23}$ The ECJ has additionally justified in its case law the supremacy clause, that a Member State cannot rely on provisions, practices or circumstances existing in its internal legal order in order to justify its failure to comply with the obligations and time-limits laid down by a EU directive. Such additional argumentation was used in the cases to the primacy of EU law. ${ }^{24}$ The supremacy of EU law is based on the statement that it should have a hig'her rank than domestic law (even the national constitutions according to the ECJ - "Simmenthal" judgment) and be hierarchically superior to it. ${ }^{25}$

Declaration No. 17 used term of "primacy" of EU law that is based on the judgement of ECJ Costa v. ENEL. Actually the term primacy of EU law results from the Costa v. ENEL implicit, because the ECJ has not used the primacy in the text of the judgment. The primacy of EU law stressed in the ECJ judgement the independency of its sources.

The ECJ explicitly stated that taking into account the primacy of EU law every national court, which had to apply any provisions of EU law, was under a duty to give the full effect to EU legal provisions, notwithstanding to the fact that under its own motion the national court had to apply the conflicting provision of national legislation (setting aside such a provision by the legislative or other constitutional means). ${ }^{26}$ Such a rule was ascertained in the latest judgement of the ECJ concerning the salary rights of judges and equal treatment, by deciding that the principle of primacy of EU law required, that a rule of domestic law, which had a constitutional status and transposed the provisions of EU law, should not be applied and its interpretation should be disregarded. Remarkably, but the ECJ decribed this as the consequences of the primacy of EU law. ${ }^{27}$

The use of the term precedence of EU law is in the judgments of the ECJ similar to the term primacy of EU law. The ECJ stressed the meaning of precedence by giving the priority to the EU legal provisions against contradicted domestic law. ${ }^{28}$ The term "supremacy of EU law" has not been used quite often in the ECJ case law.

This practice in cases involving the Republic of Lithuania just demonstrates the possible variety of different rules. In case C-391/09, the ECJ had to decide whether the rules concerning the state language could influence the freedom of movement in the EU and consequently, whether the EU legal provisions should have primacy against

\footnotetext{
23 Opinion of Advocate General Mazak, Case C-453/08, 29. April 2010, p. 29.

24 ECJ 17. September1998, Case C-144/97, p. 8, Commission v France.

25 J. H. Reestman, supra n. 20, p. 104-107.

26 ECJ 10. May 2011, Case C-147/08, p. 54, Reference for a preliminary ruling from the Arbeitsgericht Hamburg - Germany, Jürgen Römer v Freie und Hansestadt Hamburg.

27 ECJ 7. July 2011, Case C-310/10, p. 46-47, Salary rights of judges - Discrimination on grounds of membership of a socio-professional category or place of work.

28 General Court 09. September 2011, Case T-475/07, p. 144, Dow AgroSciences Ltd.
} 
Lithuanian Law. This issue has a direct relationship to the Lithuanian Constitution and its supremacy in the domestic legal order, whose Article 14 prescribes that the Lithuanian language is a state language. The ECJ decided that the rules on state language are in domestic domain, which belonged to the competence of each individual EU Member State. Nevertheless, the ECJ noted that the existing competence of the EU Member State should comply with the European Union law, and, in particular, with the Treaty provisions on freedom of every citizen of the Union to move and reside in the territory of the Member States. ${ }^{29}$ According to the ECJ, the State language constituted a constitutional asset, which preserved the nation's identity, contributed to the integration of citizens, and ensured the expression of national sovereignty, the indivisibility of the State, and the proper functioning of the services of the State and the local authorities. ${ }^{30}$

The following onerous examples of the enforcement of EU law in the Lithuanian law are extracted from the practice of the ECJ. In case C-63/06 the ECJ decided that Lithuania failed to fulfil its obligation to implement the directive because the requirements of the directive were translated incorrectly. ${ }^{31}$ This case gives an example of the uncompleted domestic regulation extended applicability of EU legal provision. It belongs to the one of the elements of the primacy of EU law.

The typical points in the infringements proceedings against Lithuania were remarkably stressed in case C-274/07 where the Commission criticized the Republic of Lithuania not for having incorrectly or insufficiently transferred the provision of the EU directive, but for failure to implement the requirements of the EU legal provision. ${ }^{32}$

The ECJ has also reviewed some rules of the Criminal Code of the Republic of Lithuania. The Court decided that the Lithuanian criminal law violated the requirement of Regulation No. 1782/2003 because under Lithuanian criminal law the production of “Cannabis Sativa L" was penalized, although under Regulation No. 1782/2003 such activity was legal. Such collision was solved in favour of Regulation No. 1782/2003 and the relevant rules of the Criminal Code of the Republic of Lithuania were revoked. ${ }^{33}$ The ECJ sets aside every rule of national law, which contradicts EU law.

29 ECJ 12. May 2011, Case C-391/09, p. 63, Freedom to move and reside in the Member States, Malgožata Runevič-Vardyn / Lukasz Pawet Wardyn.

30 Freedom to move and reside in the Member States, Malgožata Runevič-Vardyn / Łukasz Pawet Wardyn, supra n. 29, p. 84.

31 ECJ 03. February 2006, Case C-63/06, p. 15, UAB Profisa v. Muitinès departamentas prie Lietuvos Respublikos finansu ministerijos [Joint Stock Company Profisa v. Customs Department at the Ministry of Finance of the Republic of Lithuania].

32 ECJ 11. September 2008, Case C-274/07, p. 14, Commission of the European Communities/Republic of Lithuania, Single European emergency call number.

33 ECJ 11. July 2008, Case C-207/08, p. 35, Order of the Court (reference for a preliminary ruling from the Panevéžio apygardos teismas - Republic of Lithuania) - Criminal proceedings against Edgar Babanov. 
Nevertheless, the Lithuanian praxis of enforcement of EU law shows that the Lithuanian law has a tendency to avoid the conflict with EU law requirements. According to the statement of the ECJ, the number of the infringements proceedings against the Republic of Lithuania fell. ${ }^{34}$ It means that the enforcement of EU law in the Lithuanian law improved.

Analysis of the ECJ allows making the following conclusions. First of all, it is necessary to find the terminology of primacy of EU law in the jurisprudence of the ECJ, because the Court often interchangeably uses the terms of "supremacy", "precedence" and "primacy".

5. Primacy and Supremacy Clauses of EU law in the Jurisprudence of Lithuanian Courts

The analysis of the praxis of Lithuanian courts could not be complete without taking into account the comparative influences of law doctrine and judgments of courts from other EU Member States. On the other hand, it is not to be forgotten, that the principle of the primacy of EU law on the issue in the main proceedings was developed by the ECJ as a response to the references made by national courts in the European Union.

It should be noted that the main influence on the development of the Lithuanian Constitutional case law was done by the German Constitutional Court. After the famous "Maastricht - Decision" of the German Constitutional Court in 1993, which began a huge discussion in Europe about EU law in the domestic law. ${ }^{35}$ The Constitutional Court has developed for the first time specific criteria for non-applicability of EU law. The judge at the German Constitutional Court Paul Kirchhof, who was actually a judge reporter in the "Maastricht" case, officially represented the opinion about the need of cooperation between the ECJ and the Constitutional Court. Additionally, it was noticed by him that EU law would lose its roots and its power to grow by being made autonomous and separate from the EU Member States. ${ }^{36}$ Remarkably, the German Constitutional Court was again one of the first after adoption of the Treaty of Lisbon by making a clause that the Federal Republic of Germany would not recognise under some circumstances an absolute primacy and supremacy of EU law. ${ }^{37}$ The Constitutional Court developed in the "Lisbon decision" the so-called doctrine of "ultra vires control" of the competence breach done

\footnotetext{
34 ECJ Annual report (2010) p. 87 <http://curia.europa.eu/jcms/upload/docs/application/pdf/2011-05/ ra2010version integrale lt.pdf> visited 18. November 2016.

35 BVerfG [German Constitutional Court] Maastricht Judgment, 12. October 1993, No. 89-155.

36 Paul Kirchhof, The Balance of Powers between National and European Institutions, European Law Journal, (1999) 5, p. 241.

37 BVerfG [German Constitutional Court] Lisbon Judgment, 30. Juni 2009, No. 2-08.
} 
by the European Union Institutions, if such a breach was sufficiently qualified. As one of the conditions was recognized, that it should be started preliminary ruling proceedings by the ECJ concerning the legality of the EU legal act, if it is not clarified in the judgment of the ECJ already. ${ }^{38}$ The legal doctrine started to use the terms of supremacy of the national constitutions by providing the examples from EU Member States and analysing of the constitutional supremacy clause. ${ }^{39}$

Lithuanian law was not an exception from the European legal context. Nowadays the primacy and supremacy of EU law is a controversial and discussable issue in Lithuanian law and requires its analysis and application.

This issue together with the reform of the constitution of Republic of Lithuania was discussed during the process of Accession to the European Union. The main question was, during the reform, to choose between the necessity of the change of the constitution and non-change of the Lithuanian law. ${ }^{40}$

Finally, the Lithuanian legislator adopted the Constitutional Act on the Membership in the European Union, which came into force on 13 July 2004. ${ }^{41}$

According to Art. 2 of the Constitutional Act, the norms of the European Union law shall be a constituent part of the legal system of the Republic of Lithuania. Where it concerns the founding Treaties of the European Union, the norms of EU law shall be applied directly, while in the event of the collision of legal norms, they shall have primacy over the laws and other legal acts of the Republic of Lithuania. This rule of Art. 2 of the Constitutional Act should solve the questions about the recognition of the primacy and supremacy of EU law in the Lithuanian law. Nevertheless, the Lithuanian Courts case law is based on the supremacy of a national constitution. ${ }^{42}$ According to Art. 7 of the national Constitution, any legal act could not violate the constitutional requirements. The consequence of such a violation is invalidity of the legal requirements. It is a typical expression of the supremacy of the Constitution. The Constitutional Court judged that EU law could not contradict with the national Constitution. The approach of the Constitutional Court of Republic of Lithuania has been affected by their monist perspective on the

38 Ch. Tomuschat, Lisbon - Terminal of the European Integration Process? - The Judgment of the German Constitutional Court of 30. June 2009, ZaöRV (2010) p. 251.

39 M. Kumm, supra n. 9, p. 262.

40 E.Jarašiūnas, Kelios mintys apie Lietuvos dalyvavimo tarptautiniuose santykiuose konstitucinius pagrindus, Teise besikeičiančioje Europoje [Some remarks about the constitutional basics of the participation of the Republic of Lithuania in the international relations, Law in the Changing Europe], (Mykolas Romeris University Publishing Centre 2008), p. 628.

41 Law on Supplementing the Constitution of the Republic of Lithuania with the Constitutional Act "On Membership of the Republic of Lithuania in the European Union" and Supplementing Article 150 of the Constitution of the Republic of Lithuania No. IX-2343, Official Gazette No. 111-4123 (2004).

42 Judgment of the Constitutional Court of the Republic of Lithuania of 22. June 2009, About the legal act of territorial planning No. 16/07-17/07-20/08. 
relationship between the national and EU law, and it is automatically transformed into the Lithuanian law through the ratification of the Accession Treaty.

However, the Constitutional Court has limitation in the acceptance of EU law primacy. The question of recognition of primacy of EU law could cause particular problems for the Lithuanian legal order. The solution is, however, not simple. Because, the Lithuanian Constitutional Court, recognized the primacy of EU law in the domestic legal order, but not recognized the hierarchical supremacy of EU law against the Constitution. ${ }^{43}$ In case of the contradiction with the Constitution of Republic of Lithuania, EU law that has been contradicted would not be applicable. The Lithuanian point of view was stressed in German legal doctrine by Mr. Hilf, who has in the chapter of the Max Planck Encyclopaedia of Public International Law notified, that the Lithuanian constitutional provisions expressly state the primacy of EU law, that it is applicable to the non - constitutional law. ${ }^{44}$

General attorney at the ECJ Ms. Kokott has clarified an arising situation of such cases with national constitutions and its relationship to EU law as "taboo" in the judgment of the ECJ, saying that Court would not participate by the breaking of it. ${ }^{45}$

The Lithuanian legal doctrine is based on the opinion that it should be developed between the Constitutional courts and ECJ as friendly dialogue, taking into account respect to both legal systems (mutual amicability). ${ }^{46}$ It let clearly to remember on the relationship of the cooperation between the German Federal Court and the ECJ.

The opinion of former Constitutional judge Mr. Kūris was that the European Union could not be developed into a supranational structure with the novelty of the constitutional traditions. According to him, the relationship between the Lithuanian constitutional law and EU law shifts the solution from the field of "competing supremacies" to the field of application of the law. In that way, it is irrelevant which law could have supremacy because the only relevant issue is which law has to be applied. ${ }^{47}$

The recognition of common interest in the EU is the basic point of the recognition of the primacy of EU law against national law. By recognizing the fact that the Membership of Republic of Lithuania is based on the international obligation, arising from the accession treaty, Lithuania should in every case, as the EU Member, follow the

$43 \quad$ E. Jarašiūnas, supra n. 40 p. 628.

44 M. Hilf, Costa v ENEL Case, Max Planck Encyclopedia of Public International Law, <www.mpepil.com> visited 03. January 2017.

45 J. Kokott, H. Ost, Europäische Grundfreiheiten und nationales Steuerrecht, EuZW (2011) p. 496.

46 E. Jarašiūnas, supra n. 40, p. 618, 620.

47 E. Kūris, Europos Sajungos teisé Lietuvos Respublikos konstitucinio teismo jurisprudencijoje: sambūvio algoritmo paieškos, Teisé besikeičiančioje Europoje [The EU Law in the Jurisprudence of the Constitutional Court of the Republic of Lithuania: Search for the Algorithm of Coexistence, Law in the Changing Europe], (Mykolas Romeris University Publishing Centre 2008) p. 673, 707. 
law of the European Union. Lithuanian courts should in the conflict use the preliminary ruling proceedings.

In the latest Constitutional Court case law, it was recognized that the Lithuanian law should act under the presumption of applying EU law. ${ }^{48}$

The ECJ case law belongs, according to the Constitutional Court, to the legal source for interpretation of the Lithuanian law. The Lithuanian Constitutional Court applied the judgment of the ECJ before the Membership of Lithuania in the European Union. The case law shows that the court decisions were based on the European Union rules, in accordance with EU law and the Lithuanian Association Treaty requirements. ${ }^{49}$ After the Membership of Lithuania come into force, the Court applied the ECJ case law directly. But it does not change, according to the opinion of Mr. Kūris, the issue of binding the ECJ decisions to the Lithuanian Constitutional Court, because they are still a legal source for the interpretation of law, not for the decision - making it the jurisprudence of Constitutional court. ${ }^{50}$ While controlling of constitutionality of national rules, the constitutional court started the procedure of preliminary ruling and asked the ECJ. It is remarkable, because in the praxis of ECJ it is not often the case, that the constitutional court used the preliminary ruling procedure for purposes of constitutional control. ${ }^{51}$

One should agree with the opinion of Mr. Hilf, that in such situations, it is necessary to analyse the relevant national case law for finding out whether the principle of primacy has been accepted by national courts and whether it has been applied in particular cases of conflicts. The national courts have an obligation to rule on existing conflicts between EU law and national law. ${ }^{52}$ The praxis of Lithuanian ordinary courts has got nothing in common with any confrontation with the principle of primacy and supremacy of EU law.

Ordinary courts apply the preliminary rulings procedure constantly. According to the yearly overview of the jurisprudence of the Lithuanian Supreme Administrative Court has been developed into more complexities about the application of EU law. ${ }^{53}$ The new points have been arisen in the cases concerning EU financial support. The Court has directly applied in the administrative case No. A556-647/2010V. C. against the national payments agency at the Ministry of Agriculture and Ministry of

48 Constitutional Court of the Republic of Lithuania of 07. July 2011, Decision about State employment, Case Nr. 22/2008-31/2008-9/2010-35/2010, p. 3.

49 E. Kūris, supra n. 47, p 673, 707.

$50 \quad$ E. Kūris, supra n. 47 , p. 680.

51 Constitutional Court of Republic of Lithuania of 08. May 2007, Decision about reference for a preliminary ruling from the European Court of Justice, Case Nr. 47/04.

52 M. Hilf, supra n. 44, 2011.

53 Overview of the activities of the Lithuanian Supreme Administrative Court for the year 2010, <http://www. lvat.lt/media/53264/lvat_metinis_2010.pdf>, visited 24. October 2016. 
Agriculture, the general principle of EU law concerning the legal expectation. ${ }^{54}$ The Court has interpreted the rules of Commission Regulation (EC) No. 800/2008 and Council Regulation (EC) No. 1083/2006 and stated that the attorney at law office could be not treated as a receiver of financial support from the EU in a program for developing electronical business "E-Verslas LT". 55

In the next judgment of the Court, the annulment of the decision of the national payments agency to refuse to provide the status of receiver of financial support was declared. The application of EU law was for the Court judgment deciding. ${ }^{56}$ Remarkably enough, that the Lithuanian Supreme Administrative Court was the first by the asking of the ECJ, according to the preliminary ruling procedure. ${ }^{57}$ In the jurisprudence of the Lithuanian Supreme Administrative Court, EU law is applicable in the issues of freedom of movement (extradition of EU citizens), competition law, taxation law, telecommunication law, environmental law, interpretation of EU law. Their issues have a special character of administrative law as actions of state in the areas of the EU Internal Market.

The Lithuanian Supreme Court applies, as the Court of last instance, EU law constantly. In EU - relevant issues the Supreme Court is always asking the ECJ about a reference for a preliminary ruling under Article 267 of Treaty on the Functioning of the European Union. The application of EU law comes in cases of free movement of goods, freedom of establishing, consumer law protection, public procurement, interpretation and validity of EU legal acts. The application of EU law is often presented in the specific court judgment called as the overview of legal regulation and court praxis, what, in the praxis of ordinary courts, is understood as a guideline of leading cases. ${ }^{58}$

The Lithuanian Supreme Court and Supreme Administrative Court of Lithuania have been most active in the preliminary ruling procedure, because these are the courts of last instance, and they have, according to the Art. 267 of the Treaty on the Functioning of the European Union the obligation to initiate the preliminary rulings procedure and to eliminate any contradictions between EU law and national law. Furthermore, the courts of first instance give examples of correct application of preliminary

54 Supreme Administrative Court of Lithuania of 15. April 2010, Administrative case No. A556 - 647/2010.

55 Supreme Administrative Court of Lithuania of 14. October 2010, Administrative case No. A822 - 1296/2010.

56 Supreme Administrative Court of Lithuania of 26. November 2010, Administrative case No. A756 1486/2010.

57 UAB Profisa v. Muitines departamentas prie Lietuvos Respublikos finansu ministerijos [Joint Stock Company Profisa v. Customs Department at the Ministry of Finance of the Republic of Lithuania], supra $\mathrm{n}$. 31, p. 1 .

58 The relevance for the application of EU law has the following court judgments: Overview No. AC-33-1 of legal regulation and court praxis concerning consumer protection in the contractual relations of 19. November 2010, part 2; Overview No. AC-1 concerning consumer protection in the contractual relations of 24. March 2009, part 1; Overview No. A-3 of legal regulation concerning public procurement and court praxis of 29. July 2009. 
ruling proceeding by the ECJ. Especially, it is to notify the already mentioned judgment in case No. 391/09 of ECJ related to the area freedom of movement. The reference for the preliminary ruling was submitted by the Court No. 1 of the City Vilnius. ${ }^{59}$ The ECJ judgment in the area or free movement of goods was initiated by the County Court of Panevėžys during investigation of the criminal case against Mr. Babanov. ${ }^{60}$

These examples allow a conclusion about the effective application of EU law in the domestic law. The analysis shows, that any kind of contradictions between EU law and national law are avoided in the jurisprudence of the ordinary Lithuanian court.

\section{Conclusions}

Lithuanian law has met problems concerning the application of the primacy and supremacy clauses of the European Union law in its domestic legal order. According to the Lithuanian Constitutional Court, EU law has the presumption of application in Lithuanian law, nevertheless, the limitation of the sovereign powers of Republic of Lithuania and contradictions of the EU legal rule with the legal rule of Constitution would not be recognizable in the domestic law. In other cases, EU law is a constituent part of the Lithuanian legal system and takes precedence over national legal acts.

The ECJ is trying to refuse to deal with the especially sensitive questions of limitation of sovereignty of the EU Member States and transfer of these powers to the European Union. Nevertheless, the ECJ consequently developed its own rules for primacy of EU law by requiring its precedence over the conflicting national law. It should be noticed, that the differences between the terms of primacy and supremacy of the EU legal rule in the ECJ case law are not finally clarified. It comes differently in terms of describing the same legal issue. Especially, it affects the terms like "primacy", "precedence" and "supremacy".

The position of the Lithuanian Constitutional Court concerning the recognition of the EU primacy law is affected, in many points, by the jurisprudence of the German Federal Constitutional Court in "Lisbon", "Maastricht" cases. Nevertheless, the praxis of the Lithuanian Constitutional Court avoids any contradiction with EU law.

The detailed analysis of the ECJ and Constitutional Courts case laws shows some kind of "staying on line" by answering the question, what kind of law should be set aside in case of collision - EU law or the national law.

59 Freedom to move and reside in the Member States, Malgožata Runevič-Vardyn / Eukasz Pawel Wardyn, supra n. 29, p. 1.

${ }^{60}$ Order of the Court (reference for a preliminary ruling from the Panevéžio apygardos teismas - Republic of Lithuania) - Criminal proceedings against Edgar Babanov, supra n. 31, p. 1. 
The Lithuanian ordinary courts are under the influence of the ECJ and Constitutional court case law. The Lithuanian ordinary court applies preliminary ruling procedure made by the ECJ. The most analysed cases characterize this process as the "integration through law", and it could solve, by legal measures, the conflict between the EU and domestic law systems.

Vilnius, March, 5th 2017.

\section{References}

Annual report of the ECJ, 2010, p. 87. Available in: <http://curia.europa.eu>.

Barents René, The Precedence of EU Law from the Perspective of Constitutional Pluralism, European Constitutional Law Review, 5 (2009).

Burbat Daniela, Staatsbankrott als Rechtsfrage, LKV, 218 (2011).

BVerfG, 2 BvE 2/08, Lisbon Judgment of 30. Juni 2009. Available in: <http://www. bundesverfassungsgericht.de>.

BVerfGE 37, 271 ff., Solange I Judgment of 29. May 1974. Available in: <http://www. bundesverfassungsgericht.de>.

BVerfGE 73, 339, Solange II Judgment of 22. October 1986. Available in: <http://www. bundesverfassungsgericht.de>.

BVerfGE 89, 155, Maastricht Judgment of 12. October 1993. Available in: <http://www. bundesverfassungsgericht.de>.

Cambridge Draft of the Amsterdam Treaty, European L. Rev. 22, 393 (1997).

Constitutional Court of Republic of Lithuania, 08. May 2007, Vilnius, Case Nr. 47/04, Decision about reference for a preliminary ruling from the European Court of Justice. Available in: $<$ http:// www.lrkt.lt/>.

Constitutional Court of Republic of Lithuania, 22. June 2009, about the legal act of territorial planning Nr. 16/07-17/07-20/08. Available in: <http://www.lrkt.lt/>.

Constitutional Court of Republic of Lithuania, 22. June 2009, about the legal act of territorial planning Nr. 16/07-17/07-20/08. Available in: (http://www.lrkt.lt/>.

Damian Chalmers, Gareth Davies \& Giorgi Monti, European Union Law, Cambridge (2010).

Declaration Nr. 17 concerning primacy; Annex to this Final Act the Opinion of the Council Legal Service on the primacy of EC law as set out in 11197/07 (JUR 260). In: Official Journal of the European Union C 83/344, March 30. 2010. 
ECJ, 03. February 2006, Case C 63/06, UAB Profisa v. Muitinès departamentas prie Lietuvos Respublikos finansų ministerijos [Joint Stock Company Profisa v. Customs Department at the Ministry of Finance of the Republic of Lithuania]. Available in: $<$ http://curia.europa.eu>.

ECJ, 05. Februar 1963, C-26/62, Tarifcommissie N.V. Algemene Transport- en Expeditie Onderneming, van Gend en Loos. Available in: <http://curia.europa.eu>.

ECJ, 07. July 2011, Case C 310/10, Salary rights of judges - Discrimination on grounds of membership of a socio-professional category or place of work. Available in: $<$ http://curia.europa. $\mathrm{eu}>$.

ECJ, 09. October 2008, Case C 239/07, preliminary ruling under Article 234 EC from the Constitutional Court of Republic of Lithuania "Internal market in electricity - Directive 2003/54/ EC. Available in: $<$ http://curia.europa.eu $>$.

ECJ, 11. July 2008, Case C-207/08, Order of the Court (reference for a preliminary ruling from the Panevėžio apygardos teismas - Republic of Lithuania) - Criminal proceedings against Edgar Babanov. Available in: <http://curia.europa.eu>.

ECJ, 11. September 2008, Case C 274/07, Commission of the European Communities/Republic of Lithuania, Single European emergency call number. Available in: $<$ http://curia.europa.eu $>$.

ECJ, 12. May 2011, Case C 391/09, Citizenship of the Union - Freedom to move and reside in the Member States - Articles 18 TFEU and 21 TFEU, Malgožata Runevič-Vardyn / Łukasz Paweł Wardyn. Available in: $<$ http://curia.europa.eu $>$.

ECJ, 15. July 1964. Case 6/64, - Flaminio Costa v E.N.E.L. - Reference for a preliminary ruling: Giudice conciliatore di Milano - Italy. Available in: <http://curia.europa.eu>.

ECJ, 17. December 1970, Case 11-70, Internationale Handelsgesellschaft mbH v Einfuhr- und Vorratsstelle für Getreide und Futtermittel, Reference for a preliminary ruling: Verwaltungsgericht Frankfurt am Main - Germany. Available in: $<$ http://curia.europa.eu $>$.

ECJ, 28. October 2010, Case C-350/08, European Commission/Republic of Lithuania "National marketing authorization granted before accession". Available in: $<$ http://curia.europa.eu $>$.

Gianviti/Krueger/Pisani-Ferry/Sapir/von Hagen, A European Mechanism for Sovereign Debt Crisis Resolution: A Proposal, Bruegel, (2010).

Giuliano Amato / Jacques Ziller, The European Constitution - Cases and Materials in EU and Member States Law, Primacy of EU Law, p. 90 Edward Elgar (2007).

Graig Paul, The ECJ, National Courts and the Supremacy of Community Law. Available in: $<$ http:// www.ecln.net/rome2002/craig.pdf>.

Greve Holger, Staatsbankrott als Rechtsfrage, EuZW, 367 (2011). 
Hasselbach Kai, Der Vorrang des Gemeinschaftsrechts vor dem nationalen Verfassungsrecht nach dem Vertrag von Amsterdam, JZ (1997).

Hilf Meinhard, Costa v ENEL Case, in Max Planck Encyclopedia of Public International Law. Available in: <www.mpepil.com> (2011).

Jarašiūnas Egidijus, Kelios mintys apie Lietuvos dalyvavimo tarptautiniuose santykiuose konstitucinius pagrindus, Teise besikeičiančioje Europoje [Some remarks about the constitutional basics of the participation of the Republic of Lithuania in the international relations], Mykolas Romeris University Publishing Centre, (2008).

Karen J. Alter, Establishing the Supremacy of European Law - The Making of an International Rule of Law in Europe, Oxford - University Press (2001).

Kirchhof Paul, The Balance of Powers between National and European Institutions, ELJ 225 (1999).

Koen Lenaerts and Piet Van Nuffel, Constitutional Law of the European Union, Thomson / Sweet \& Maxwell (2005).

Kokott Juliane, Ost Hartmut, Europäische Grundfreiheiten und nationales Steuerrecht, EuZW, 496 (2011).

Kumm Mattias, The jurisprudence of Constitutional Conflict: Constitutional Supremacy in Europe before and after the Constitutional Treaty, European Law Journal, v. 11, n. 3, p. 262 (2005).

Kūris Egidijus, Europos Sajungos teisė Lietuvos Respublikos konstitucinio teismo jurisprudencijoje: sambūvio algoritmo paieškos, Teisè besikeičiančioje Europoje [The EU Law in the Jurisprudence of the Constitutional Court of the Republic of Lithuania: Search for the Algorithm of Coexistence, Law in the Changing Europe], Mykolas Romeris University Publishing Centre, (2008).

Law on Supplementing the Constitution of the Republic of Lithuania with the Constitutional Act "On Membership of the Republic of Lithuania in the European Union" and Supplementing Article 150 of the Constitution of the Republic of Lithuania No. IX-2343, Official Gazette 2004, Nr. 1114123 .

Overview of the activities of the Lithuanian Supreme Administrative Court for the year 2010. Available in: $<$ http://www.lvat.lt/media/53264/lvat_metinis_2010.pdf $>$.

Schmid Christoph U, Ways Out of the Maquis Communautaire on Simplification and Consolidation and the Need for a Restatement of European Primary Law, May 1999, European University Institute, Working Paper RSC No 99/6.

Streinz Rudolf, Europarecht, CF Müller Verlag (2007).

Supreme Administrative Court of Lithuania of 14. October 2010, in the administrative case Nr. A822 - 1296/2010. Available in: <http://www.lvat.lt/>. 
Supreme Administrative Court of Lithuania of 15. April 2010, in the administrative case Nr. A556 - 647/2010. Available in: <http://www.lvat.lt/>.

Supreme Administrative Court of Lithuania of 26. November 2010, in the administrative case Nr. A756 - 1486/2010. Available in: <http://www.lvat.lt/>.

Supreme Court of Lithuania of 19. November 2010, Overview Nr. AC-33-1 of legal regulation and court praxis concerning consumer protection in the contractual relations, part 2. Available in: $<$ http://www.lat.lt/default.aspx?item=home $>$.

Supreme Court of Lithuania of 24. March 2009, Overview Nr. AC-1 concerning consumer protection in the contractual relations, part 1 . Available in: $<$ http://www.lat.lt/default.aspx?item=home $>$.

Supreme Court of Lithuania of 29. July 2009, Overview Nr. A-3 of legal regulation concerning public procurement and court praxis. Available in: $<\mathrm{http}: / \mathrm{www} .1 \mathrm{at} .1 \mathrm{t} / \mathrm{default}$.aspx?item=home $>$.

Tomuschat Christian, Lisbon - Terminal of the European Integration Process? - The Judgment of the German Constitutional Court of 30. June 2009, ZaöRV p. 251 (2010).

Treaty establishing a Constitution for Europe. In: Official Journal of the European Union C 310/12, December 16. 2004.

Treaty of the European Union. In: Official Journal of the European Union C 83/13, March 30. 2010.

Treaty on Functioning of the European Union. In: Official Journal of the European Union C 83/47, March 30. 2010. 